\title{
Energy Usage and Benefit-Cost Analysis of Castor Production in Haryana
}

\author{
Nirmal Kumar, Neeraj Pawar, D.K. Bishnoi, Jitender Bhatia and Raj Kumar"
}

Department of Agricultural Economics, CCS Haryana Agricultural University, Hisar, Haryana, India

"Corresponding author: rajkumarkashyap301@gmail.com (ORCID ID: 0000-0003-3089-6234)

Received: 03-07-2019

Revised: 09-10-2019

Accepted: 23-11-2019

\begin{abstract}
The study used farm level data collected from rain-fed and irrigated castor seed cultivators from three purposively selected districts namely Rewari, Sirsa and Hisar of Haryana on the basis of highest acreage under castor crop. From each selected district, two villages were selected purposively having large number of castor cultivators. Sixty castor cultivators were interacted to extract relevant information related to various energy utilized in castor seed production using survey method. The aim of this research is to determine the energy input and output involved in castor production in the Haryana. The average energy consumption of the farms investigated in this study is $11064.18 \mathrm{MJha}^{-1}$ of the total energy, 23.67 per cent is direct and 56.56 per centwas indirect. Renewable energy accounts for $3.49 \%$ and energy usage efficiency is found to be 5.92. The total energy input into the production of one kilogram of average castor was estimated to be $8.55 \mathrm{MJ}$. The dominant contribution to input is energy in the form of nitrogen fertiliser $(32.86 \%)$, followed by water for diesel- oil (20.61\%) and irrigation (19.77\%). The cost of castor production per hectare is found to be $₹ 97412 \mathrm{ha}^{-1}$ in the region, with $52.70 \%$ of this beingfixed costs. It can be concluded that intensive castor farms are being operated in the area since the fixed cost was quite high. As a result of benefit-cost ratio (1.48) analysis, castor production was found to be economically efficient.
\end{abstract}

Highlights

( Castor growing is a step forwards the diversification and commercialization of agriculture. Thebenefitcost ratio in was found to be economically efficient in castor cultivation.

Keywords: Castor, input-output ratio, energy, production, renewable and non-renewable energy

Castor (Ricinus communis L.) is cultivated around the world because of the commercial importance of its oil. Castor is a small annual plant. It ranges from 1 to 7 meters in height. It has well-developed roots, with green and reddish stems which become hollow with age. The fruit is a spherical capsule with small grey seeds with brown spots. The castor plant appears to have originated in eastern Africa, especially around Ethiopia. The major castor growing countries like India, China, Brazil, Paraguay and Thailand sharing 82.58 percent of total area in the world.India alone contributed about 70 per cent of total castor area at global level.

It now grows throughout the warm-temperate and tropical regions and flourishes under a variety of climatic conditions. India rank first in the area, production and second rank in productivity of castor crop in the world. During the year 2016 India occupies an area of 870 thousand hectare $(69.22 \%)$ with production of 1554 thousand tonnes $(87.42 \%)$ of the world. India has second position in productivity of castor crop about $1786.2 \mathrm{Kg} / \mathrm{ha}$ during the year 2016 of the world (www.indiastat.com 2016). The Indian variety of castor has an oil content of 48 per cent and 42 per cent can be extracted, while the

How to cite this article: Kumar, N., Pawar, N., Bishnoi, D.K., Bhatia, J. and Kumar, R. (2019). Energy usage and benefit-cost analysis of castor production in Haryana. Economic Affairs, 64(4): 789-794. 
cake retains the rest. Castor grows under tropical conditions. A hot and humid climate is required for its production. Castor oil obtained from castor seed is inedible but it has great industrial importance. Castor oil is uses for commercial purpose because of its versatile, renewable resource having vast and varied applications such as lubricating grease, surfactants, surface coatings, telecom, engineering plastics, pharma, rubber chemicals, nylons, soaps, hydraulic brake fluids, paints and polymers and perfumery products. Castor meal has uses in agriculture as organic manure. The chemical structure of castor oil is of great interest because of the wide range of reactions it affords to the oleochemical industry and the unique chemicals that can be derived from it. These derivatives are at par with petrochemical products for use in several industrial applications. In fact, they are considerably superior since they are from renewable sources, bio-degradable and eco-friendly. Castor oil and its derivatives find uses in agriculture, cosmetics, electronics \& telecommunications, food, lubricants, paints, inks and adhesives, paper, perfumeries, pharmaceuticals, plastics \& rubber and textile chemicals.

\section{MATERIALS AND METHODS}

The present investigation was carried out during the year 2018-19 in three districts namely Rewari, Sirsa and Hisar of Haryana state. The districts were selected on the basis of large acreage under castor cultivation. Further, sixty (60) cultivators from six villages (two villages from each selected district) were interviewed on random basis to extract relevant information pertaining to the extent of use of various resources like seed, chemical fertilizers, plant protection chemicals, irrigation, farm machinery \& labour used for various field operation and output. The prevailing market prices of purchased inputs, hired labour, imputed value of family labour were taken into account to work out economic viability of castor seed cultivation.

The objective is to study the impact of mechanization of critical operations like sowing, inter cultivation and sheller/threshing of crop. Similarly, theenergy consumptionof the variousoperations of the castor crop production under human and mechanized method has been recorded. The data on time period for each operation, labour used (number) for each operation, energy used,were converted into suitable energy units and expressed in mega joules per hectare (MJ/ha.). Energy equivalents of inputs and outputs are given in Table 2. The inputs used in the calculation of agricultural energy use include human labour, machinery, electricity, fertilizers, pesticides, and seeds. For the estimation of energy input for agriculture, our man-days for agricultural workers were taken on an average eight hours for men and ten hours for women. The measurements of fuel and electricity consumption, operation time and crop yield were selected farmers. The kinds of farm implements were used shown in Table 1 . The energy use values were calculated by multiplying the input and output components with their energy equivalents, as expressed in Table 2 (Mandal et al. 2002). The study also benefited from previous research and studies about energy analysis in agriculture. The various energy inputoutput parameters like energy ratio (energy use efficiency), energy productivity, specific energy (energy intensity) and net energy were calculated as follow:

Energy ratio $=\frac{\text { Energy output }\left(M J \mathrm{~h}^{-1}\right)}{\text { Energy intput }\left(M J \mathrm{ha}^{-1}\right)}$

Energy productivity $=\frac{\text { Castor yield }\left(\mathrm{Kg} \mathrm{ha}^{-1}\right)}{\text { Energy intput }\left(M J \mathrm{Ma}^{-1}\right)}$

Specific energy $\left(\mathrm{kg} \mathrm{ha}^{-1}\right)=\frac{\text { Energy input }\left(M J \mathrm{ha}^{-1}\right)}{\text { Castor uield }\left(K g h a^{-1}\right)}$

Energy intensiveness $\left(\mathrm{MJ} ₹ \mathrm{ha}^{-1}\right)=$

$$
\frac{\text { Total energy }\left(M J h a^{-1}\right)}{\text { Production cost }\left(R s . h a^{-1}\right)}
$$

Net energy = Energy output $(M J$ ha-1) - Energy input (MJ ha-1)

Table 1: Use of farm implements in castor

\begin{tabular}{ll}
\hline Operation & Use of implements in castor \\
\hline Land & Mould board plough, Rotovator, disc \\
preparation & harrow, cultivator, planker \\
Sowing & $\begin{array}{l}\text { Seed cum fertilizer drill/ Hand } \\
\text { dibbling manual }\end{array}$
\end{tabular}




\begin{tabular}{ll} 
Inter culturing & Power weeder/power tiller \\
Need-based & Tractor mounted sprayer Motorized/ \\
plant protection & power sprayers \\
Harvesting & Secateurs/sickle \\
Post-harvest & Using castor shellers/Threshers \\
\hline
\end{tabular}

\section{RESULTS AND DISCUSSION}

The agricultural practices used in castor production in the research area are presented in Table 3. The land is tilled twice between June-July using a mould board plough, rotovator, disc harrow, cultivator and planker. Then, an average of $10-12.5 \mathrm{~kg} \mathrm{ha}^{-1}$ in unirrigated and 5-6.5 Kgha ${ }^{-1}$ in irrigated castor seed is used. The main varieties of castor seed used in the region are GCH-4, 5, 6, DCH -32, 177, 519. Castor is irrigated by the "sprinkler and flood irrigation method" about 3-4 times between September to January. Fertilizer is applied approximately 3 times within the July to December. Plant protection is started from Julyup to ends ofOctober with an average of three to four pesticide and herbicide applications. On average, the castor crop is hoed two times by hand and two times by machine during the period of August-September. The castor is generally harvested by manuallyfour times during month of November, January, March and May.

Table 2: Energy content of castor production inputs and output

\begin{tabular}{|c|c|c|}
\hline Items & $\begin{array}{l}\text { Energy } \\
\text { Content } \\
\left(\mathbf{M J} \text { unit }^{-1}\right)\end{array}$ & References \\
\hline Human labour (h) & 1.96 & $\begin{array}{l}\text { (Singh 2002, Singh and } \\
\text { Chandra 2001; Mani et al. } \\
\text { 2007) }\end{array}$ \\
\hline \multicolumn{3}{|l|}{ Machinery } \\
\hline Tractor 50 kW (h) & 41.4 & \multirow{5}{*}{$\begin{array}{l}\text { (Tsatsarelis 1993; Fluck } \\
\text { 1985; Loewer et al. 1977) }\end{array}$} \\
\hline Plough (h) & 22.8 & \\
\hline Sprayer (h) & 23.8 & \\
\hline Wagon (h) & 71.3 & \\
\hline Pump (h) & 2.4 & \\
\hline \multicolumn{3}{|l|}{ Fertilizers } \\
\hline $\mathrm{N}(\mathrm{kg})$ & 60.6 & \multirow{3}{*}{$\begin{array}{l}\text { (Singh 2002; Singh and } \\
\text { Chandra 2001; Mandal et } \\
\text { al. 2002; Mani et al. 2007; } \\
\text { Shrestha 1998) }\end{array}$} \\
\hline $\mathrm{P}(\mathrm{kg})$ & 11.1 & \\
\hline $\mathrm{K}(\mathrm{kg})$ & 6.7 & \\
\hline Insecticides (kg) & 278 & (Hülsbergen et al. 2002; \\
\hline Fungicides (kg) & 276 & Dalgaard et al. 2001; Wells \\
\hline Herbicides (kg) & 288 & 2001; Meul et al. 2007) \\
\hline
\end{tabular}

\begin{tabular}{|c|c|c|}
\hline Seed (kg) & 14.7 & \multirow{2}{*}{ (Gopalson et al. 1978) } \\
\hline Straw (All crops) & 12.5 & \\
\hline Diesel (1) & 56.31 & $\begin{array}{l}\text { (Singh 2002; Singh and } \\
\text { Chandra 2001; Mandal et } \\
\text { al. 2002; Mani et al. 2007) }\end{array}$ \\
\hline $\begin{array}{l}\text { Water for } \\
\text { irrigation }\left(\mathrm{m}^{3}\right)\end{array}$ & 0.63 & (Yaldiz et al. 1993) \\
\hline
\end{tabular}

Table 3: Agricultural operations in castor cultivation in selected district of Haryana

\begin{tabular}{ll}
\hline Agricultural practices & Periods/Frequency \\
\hline Common varieties & GCH-4, 5, 6, DCH -32, 177, \\
& 519 \\
Seed $\left(\mathrm{kgha}^{-1}\right)$ & $10-12.5 \mathrm{Kg} /$ ha (Un-irrigated) \\
& $5-6.5 \mathrm{Kg} / \mathrm{ha}$ (Irrigated) \\
Land preparation & June- July (using plough, \\
& harrow and cultivator) \\
Average tilling number & $4-5$ \\
Thinning & August-September \\
Average number of thinning & $1-2$ \\
Sowing & June-July \\
Irrigation border period & September-December- \\
Number of irrigation & January \\
borders & $3-4$ \\
Fertilization period & July-September-December \\
Average number of & 3 \\
fertilization applications & \\
Spraying period & July-September-October \\
Average number of spraying & $3-4$ \\
Hoeing period & August-September \\
Average number of hoeing & 2 times by tractor and 2 \\
Harvesting period & times by hand \\
& November-January-March- \\
& May \\
\hline
\end{tabular}

Per hectare the inputs used in castor cultivation and their energy equivalents and energy ratio are presented in Table 4. The results revealed that total 172.63 hours (91.05\%) of human labour and 16.97 hours $(8.95 \%)$ of machinery power were consumed. Seventy four percent of the total human labour were being used for harvesting whereas, rest of 25 per cent labour were used for land preparation andother applications such as fertilization, pest control, and irrigation.Energy used through diesel, fertiliser and human beings played a significant role in the castor production. Based on the energy equivalents of the inputs and output presented in the Table 1, the average total energy wereconsumed 11064.18 MJ per 
hectare. It was $49740 \mathrm{MJha}^{-1}$ in Antalya (Yilmaz et al. 2005), 7 200-12 264 MJha $^{-1}$ in Punjab (Manes and Singh, 2005), and 40557 MJha $^{-1}$ in Tamil Nadu (Sing et al. 1997). These differences can be explained by the inefficiencies of energy input usage and castor yield per hectare.

Table 4: Energy consumption and energy inputoutput relationship for castor production

\begin{tabular}{|c|c|c|c|c|}
\hline & 1 & 2 & $1 * 2$ & \\
\hline Input & 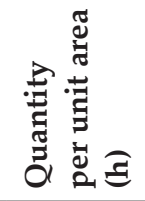 & 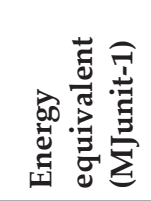 & 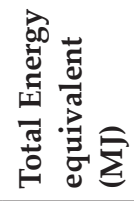 & 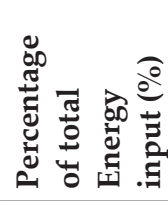 \\
\hline $\begin{array}{l}\text { Human labour } \\
\text { (h) }\end{array}$ & 172.63 & - & 338.35 & 3.06 \\
\hline $\begin{array}{l}\text { Land } \\
\text { preparation }\end{array}$ & 8.4 & 1.96 & 16.46 & 0.15 \\
\hline Sowing/diblling & 21.6 & 1.96 & 42.34 & 0.38 \\
\hline $\begin{array}{l}\text { Cultural } \\
\text { practices }\end{array}$ & 32.13 & 1.96 & 62.97 & 0.57 \\
\hline Picking & 108 & 1.96 & 211.68 & 1.91 \\
\hline Other practices & 2.5 & 1.96 & 4.90 & 0.04 \\
\hline Machinery (h) & 16.97 & & 539.28 & 4.87 \\
\hline $\begin{array}{l}\text { Land } \\
\text { preparation }\end{array}$ & 8.4 & 41.4 & 347.76 & 3.14 \\
\hline $\begin{array}{l}\text { Cultural } \\
\text { practices }\end{array}$ & 4.57 & 2.4 & 10.97 & 0.10 \\
\hline Threshing & 3.5 & 41.4 & 144.90 & 1.31 \\
\hline Other practices & 0.5 & 71.3 & 35.65 & 0.32 \\
\hline $\begin{array}{l}\text { Total fertilizer } \\
(\mathrm{Kg})\end{array}$ & 130 & - & 4281 & 38.69 \\
\hline Nitrogen (Kg) & 60 & 60.6 & 3636.00 & 32.86 \\
\hline $\begin{array}{l}\text { Phosphorus } \\
(\mathrm{Kg})\end{array}$ & 40 & 11.1 & 444.00 & 4.01 \\
\hline Potassium (Kg) & 30 & 6.7 & 201.00 & 1.82 \\
\hline Seeds & 3.24 & 14.7 & 47.63 & 0.43 \\
\hline $\begin{array}{l}\text { Insecticide } \\
\text { (litres) }\end{array}$ & 5 & 278 & 1390.00 & 12.56 \\
\hline Diesel-oil (litres) & 40.5 & 56.31 & 2280.56 & 20.61 \\
\hline Irrigation & 3472 & 0.63 & 2187.36 & 19.77 \\
\hline $\begin{array}{l}\text { Total energy } \\
\text { input }\left(\mathrm{MJha}^{-1}\right)\end{array}$ & 3840.34 & 428.04 & 11064.18 & 100.00 \\
\hline Yield (Kg ha $\left.{ }^{-1}\right)$ & 2902 & 14.74 & 42659 & \\
\hline Straw $\left(\mathrm{Kg} \mathrm{ha}^{-1}\right)$ & 1825 & 12.5 & 22813 & \\
\hline
\end{tabular}

Total output energy (yield + stalk) 65472

Energy output-input ratio $\quad 5.92$

Specific energy (E.I. MJ/ha /Castor 3.81

yield $\mathrm{Kg} / \mathrm{ha}^{-1}$ )

Energy productivity $(\mathrm{Kg} / \mathrm{MJ})$
Production cost $₹$ ha $^{-1}$

97412

Specific energy (E.I. MJ/ha /Castor 8.65

yield $\mathrm{Kg} / \mathrm{ha}^{-1}$ )

Energy intensiveness $\mathrm{MJ} / \mathrm{ha} / \mathrm{F}^{\mathrm{F}} \quad 0.11$

Net energy returns (MJ/ha) (EO - EI)) 54408

In our study, the energy input of chemical fertiliser $(51.56 \%)$ in castor production represents the biggest share of the total energy inputs. Water for dieseloil and irrigation inputs follow with 20.61 and $19.77 \%$, respectively. The energy equivalence of these three inputs are 5671, 2280.56 and 2187.36 $\mathrm{MJha}^{-1}$, in the same order. As can be seen from Table 4, insecticides, harvesting, and seed consumed $1390.90 \mathrm{MJha}^{-1}(12.56 \%), 211.68 \mathrm{MJha}^{-1}(1.91 \%)$, and $47.63 \mathrm{MJha}^{-1}(0.43 \%)$, respectively. The output-input ratio was 5.92 which indicate that one $\mathrm{MJ} \mathrm{ha}^{-1}$ energy produces near about six $\mathrm{MJ} \mathrm{ha}^{-1}$ (Kumar and Sridhara, 2018). The indiscriminate uses of various inputs have resulted in a high cost of production and deterioration in environmental and soil quality and economic situation of the farmers.Thus, there is a need to balance the use of energy inputs and to improve the energy productivity of castor cultivation. This can be achieved through optimum use of various energy inputs.

Production costs and returns are also given in Table 4. The results show that the cost per hectare of castor production was ₹ 97412. Castor yield in the area under investigation was about $2902 \mathrm{~kg} \mathrm{ha}^{-1}$. Specific energy was found to be $8.65 \mathrm{MJkg}^{-1}$. In other words, for each kilogram of castor produced, about 8.65 MJ of energy is consumed. Energy intensiveness was calculated by dividing total energy into the production cost and was found to be $0.11 \mathrm{MJha}^{-1}$. Net energy was estimated to be $54408 \mathrm{MJha}^{-1}$.

The forms of energy inputs used in castor production are given in Table 5. Energy input is considered in two different forms; direct and indirect energy or renewable and non-renewable energy. As can be seen from the table, a total of $11064.18 \mathrm{MJ} \mathrm{ha}^{-1}$ energy was used. Of this energy, $6258 \mathrm{MJ} \mathrm{ha}^{-1}$ (56.56\%) was indirect, including fertilizer chemicals, machinery and seeds, and $2619 \mathrm{MJ}^{-1}$ (23.67\%) was direct energy, including human labour and diesel-oil.The renewable energy (including human labour and seed energy) ratio was 3.49 while in non-renewable energy (including diesel, electricity, chemicals, and fertiliser and machinery energy) ratio was $76.74 \%$ of 
total used energy. The high ratio of non-renewable energy in the total used energy inputs causes negative effects on the sustainability in agricultural production of small-scale farms. In particular, castor requires a high amount of capital and input. However, small-scale farms are characterised byinsufficient capital and relatively cheap family labour. So, as the renewable energy ratio increases in the product inputs, farms feel more comfortable due to less dependence on farm outputs. Although, there is important technological innovation in castor productionin countries where agricultural production is based on family operations (smallscale farms), the renewable energy ratio is very important for production decisions, thus resulting in production sustainability. Therefore, a reduction in the total non-renewable energy ratio, specifically in chemical and fertiliser usage would have positive effects on the sustainability of castor production as well as other positive environmental effects.

Table 5: Energy consumption under different modes of energy source for castor production

\begin{tabular}{|c|c|c|c|}
\hline Energy forms & Mjha' $^{-1}$ & $\begin{array}{l}\text { Percentage of } \\
\text { total energy } \\
\text { input }(\%)\end{array}$ & \\
\hline Direct energy & 2619 & 23.67 & Human, diesel \\
\hline $\begin{array}{l}\text { Indirect } \\
\text { energy }\end{array}$ & 6258 & 56.56 & $\begin{array}{l}\text { Fertilizer, chemicals, } \\
\text { machinery, seeds }\end{array}$ \\
\hline $\begin{array}{l}\text { Renewable } \\
\text { energy }\end{array}$ & 386 & 3.49 & Human, seeds \\
\hline $\begin{array}{l}\text { Non- } \\
\text { renewable } \\
\text { energy }\end{array}$ & 8491 & 76.74 & $\begin{array}{l}\text { Diesel, electricity, } \\
\text { chemicals, fertilizer, } \\
\text { machinery }\end{array}$ \\
\hline
\end{tabular}

Table 6: Economic analysis of castor production in Haryana (₹/ha)

\begin{tabular}{ll}
\hline Cost items & Value \\
\hline Total Variable Cost & $46075(47.30)$ \\
Total Fixed Cost & $51337(52.70)$ \\
Total Cost & $97412(100.00)$ \\
Selling price & 4889 \\
Castor yield (Kg/ha) & 2902 \\
Total production value & 141598 \\
Gross returns & 143743 \\
Net returns & 46331 \\
B:C ratio & 1.48 \\
\hline
\end{tabular}

An economic analysis of castor production is given in Table 6. According to the table, cost of castor production is about $₹ 97412 \mathrm{ha}^{-1}(47.30 \%$ of the total is variable and $52.70 \%$ is fixed cost). Net return was found to be ₹ $46331 \mathrm{ha}^{-1}$. In our study, the benefitcost ratio of the castor production was calculated by dividing the gross product value into the total production cost in order to determine economic efficiency. The benefit-cost ratio $(B / C)$ was found to be 1.48 .

\section{CONCLUSION}

In this study, an energy output-input analysis was performed for castor production in the Haryana. Total energy consists of the sum of all energy components used in production. In this study, total energy consumption of castor production in Haryana agriculture was determined to be 11064.18 MJ per hectare. The results indicated that the level of fertiliser was one of the significant determinants of the total energy input, followed by diesel oil and irrigation. Energy use efficiency is 5.92. The total indirect energy consumption represents $56.56 \%$ in castor production, and $23.67 \%$ is direct energy. This indicates that there was a capital intensive production system in the region. Thus, input usage is high and uncontrolled in Haryana. Therefore, to be able to ensure the sustainability of castor production, farms should be encouraged to decrease their input usage level towards organic production. This approach should be taken until the optimum farm size is reached. In addition, environmental damages would decrease concurrently. In this research, net return was calculated as ₹ $46331 \mathrm{ha}^{-1}$. Benefit-cost ratio was found to be 1.48. As a result, farm size should be increased by decreasing population density on the land. The capital requirements of farm enterprisers should be overcome by input and credit subsidies. With the appropriate input and price policy applications, excessive water and chemicals usage must be intercepted. Agricultural advising should also be activated. Due to high production costs in Haryana, the competitive strength of Haryana castor producers is low. Castor production should be encouraged for self- sufficiency and entrance into world markets.

\section{ACKNOWLEDGEMENTS}

Authors wish to acknowledge Chaudhary Charan Singh Haryana Agricultural University and all the 
$\underset{\text { AESRA }}{\int_{2}}$ Kumar et al.

farmers who participated in the study and made the study successful.

\section{REFERENCES}

Anonymous, 2016. www.indiastat.com

Arefe, R., Majid A. A., Barat, G., Behnam, Z. and Mohammad, S. 2017. A Case Study of Energy Balance and Economic Analysis of Castor Cultivation in Iran. Journal of Advanced Agricultural Technologies, 4(3): 290-295.

Dalgaard, T., Halberg, N. and Porter, J.R. 2001. A model for fossil energy use in Danish agriculture used to compare organic and conventional farming. Agricultural Ecosystem and Environment, 87: 51-65.

Erdal, D., Handan, A., Bekir, D. and Yalcin, Y. 2009. Energy usage and benefit-cost analysis of cotton production in Turkey African. Journal of Agricultural Research, 4(7): 599-604.

Fluck, R.C. 1985. Energy sequestered in repairs and maintenance of agricultural machinery. Transactions of the American Society of Agricultural Engineers, 28: 738-44.

Gopalan, C.B., Ramasastri, V. and Balasubramanian, S.C. 1997. Nutritive value of Indian foods. National Institute of Nutrition Indian council of medical research, Hyderabad: 47-58.

Hülsbergen, K.J., Feil, B. and Diepenbrock, W. 2002. Rates of nitrogen application required to achieve maximum energy efficiency for various crops: results of a long-term experiment. Field Crops Res., 77: 61-76.

Kumar, N.A.H. and Sridhara, S. 2018. Energy Requirement and Management in Castor Production. International Journal Pure Applied Bioscience, 6(2): 304-310.

Loewer, O.J., Benock, G., Gay, N., Smith, E.M., Burgess, S., Wells, L.G., Bridges, T.C., Springate, L., Boling, J.A., Brattord, G. and Debertin, D. 1977. Production of beef with minimum grain and fossil energy inputs. Vol.I, II, III. Report to NSF.

Mandal, K.G., Saha, K.P., Ghosh, P.K., Hati, K.M. and Bandyopadhyay, K.K. 2002. Bioenergy and economic analysis of soybean based crop production systems in Central India. Biomass and Bio Energy, 23: 33-45.
Manes, G.S. and Singh, S. 2005. Sustainability of cotton cultivation through optimal use of energy inputs in Punjab IE (I) Journal AG, 86: 61-64.

Mani, I., Kumar, P., Panwar, J.S. and Kant, K. 2007. Variation in energy consumption in production of wheat-maize with varying altitudes in Hilly Regions of Himachal Pradesh, India. Energy, 32: 2336-2339.

Meul, M., Nevens, F., Reheul, D. and Hofman, G. 2007. Energy use efficiency of specialized dairy, arable and pig farms in Flanders. Agricultural Ecosystem and Environment, 119: 135-44.

Ozkan, B., Akcaoz, H. and Karadeniz, C.F. 2004. Energy requirement and economic analysis of citrus production in Turkey. Energy Conversion Mgt., 45: 1812-30.

Shrestha, D.S. 1998. Energy input-output and their cost analysis in Nepalese agriculture.agriculture. http://www. public.iastate.edu/ dev/pdfdocs/Energy.PDF.

Singh, J.M. 2002. On farm energy use pattern in different cropping systems in Haryana India, Master of Science Thesis (Unpublished), International Institute of Management University of Flensburg, Germany.

Singh, R.S. and Chandra, H. 2001. Technological impact on energy consumption in rainfield soybean cultivation in Madhya Pradesh. Applied Energy, 70: 193-213.

Tsatsarelis C.A. 1993. Energy inputs and outputs for soft winter wheat production in Greece. Agric. Ecosyst. Environ., 43: 10-18.

Wells D. 2001. Total energy indicators of agricultural sustainability: dairy farming case study. Technical Paper 2001/3. Min. Agric. Forestry, Wellington, http://www. maf.govt.nz

Yaldiz, O., Ozturk, H.H., Zeren, Y. and Bascetincelik, A. 1993. Energy use in field crops of Turkey. $5^{\text {th }}$ International Congress of Agricultural Machinery and Energy, Kusadası. Turkey.

Yilmaz, I., Akcaoz, H. and Ozkan, B. 2005. An analysis of energy use and input costs for cotton production in Turkey. Renewable Energy, 30: 145-55. 